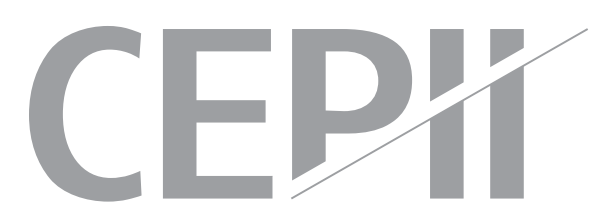

\title{
Trade policy and industrial policy in China: What motivates public authorities to apply restrictions on exports?
}

Julien Gourdon, Stéphanie Monjon \& Sandra Poncet

\section{Highlights}

- During the period 2002-2012, Chinese authorities used two major export taxation instruments targeting exports -export tax and export VAT rebate- in a complementary way with the aim of achieving their industrial policy.

- Some are officially stated such as promoting high-technology productions or environment protection but others do not appear in official documents, such as subsidizing downstream sectors.

- We also observed that China used those instruments in a dynamic way to address temporary shocks, for example to temper food price rises or to support strategic sectors sensitive to price competitiveness in the middle of the financial crisis. 


\section{Abstract}

This work investigates the motivations behind the Chinese fiscal policy on exports. It relies on very detailed product level (HS 6 digit) data over the period 2002-12 covering both export tax and export VAT rebate. It aims to uncover the respective importance of the various policy motivations and how they evolved over time. Our empirical analysis relates the tax rates to proxies of official objectives pursued by the Chinese public authorities such as those related to the promotion of technology or protection of the environment but also other unstated motives pertaining to subsidization of downstream sectors and terms of trade. Our results suggest that the Chinese fiscal policy targeting exports follows a variety of objectives whose relative importance changed over the period 2002-2012.

\section{Keywords}

Trade policy, industrial policy, China, VAT system, export tax.

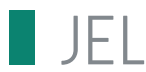

F10, F14, Q56.

\section{Working Paper}

\section{CEPI}

CEPII (Centre d'Etudes Prospectives et d'Informations Internationales) is a French institute dedicated to producing independent, policyoriented economic research helpful to understand the international economic environment and challenges in the areas of trade policy, competitiveness, macroeconomics, international finance and growth.
CEPII Working Paper

Contributing to research in international economics

(c) CEPII, PARIS, 2015

All rights reserved. Opinions expressed in this publication are those of the author(s) alone.

$\begin{array}{ll}\text { Editorial Director: } & \text { CEPII } \\ \text { Sébastien Jean } & 113, \text { rue de Grenelle } \\ & 75007 \text { Paris } \\ \text { Production: } & +33153685500 \\ \text { Laure Boivin } & \\ \text { No ISSN: } 1293-2574 & \text { Prw.cepii.fr }\end{array}$




\title{
Trade policy and industrial policy in China: What motivates public authorities to apply restrictions on exports ${ }^{1}$
}

\author{
Julien Gourdon*, Stéphanie Monjon ${ }^{\dagger}$ and Sandra Poncet ${ }^{\xi}$
}

\section{Introduction}

Taxation of Chinese exports has received growing attention in recent years as the Chinese government made frequent large adjustments, either upwards or downwards, in the level of export taxes and export VAT-rebates (Evenett et al., 2012) ${ }^{3}$ In the period $2002-12,75 \%$ of products at the HS8-digit level underwent at least one change in their VAT-refund rate. Export taxes target fewer products than the export VAT-rebate, but affected almost four times more HS8-digit product lines in 2012 than in 2002. On June 22, 2010, for example, the Chinese Ministry of Finance and the State Administration of Taxation issued a circular revoking the export VAT refund for 406 items, including steel products, nonferrous metals products, pesticides, pharmaceutical and chemical products and plastic, rubber and glass products (Cai Shui (2010) No. 57). The same year, China announced a 15\% to 25\% increase in export tax on certain rare-earth minerals, including neodymium and lanthanum chloride and on ferroalloy containing more than $10 \%$ rare earth elements (WTO, 2012). Both these adjustments unambiguously increased the export costs of the products targeted.

The official statements announcing the tax adjustments often contain justifications for the policy change. They stress the desire to promote products with high added-value or technological contents and to reduce the export share of "undesirable industries", in particular those producing polluting goods or consuming large amounts of energy and natural resources. From 2008 onwards, the fiscal tools were adjusted in an attempt to mitigate the negative repercussions of the international crisis. Nevertheless, theoretical literature also reveals that export restrictions can be motivated by other considerations, which may hurt China's trade partners, for instance the subsidization of downstream industries or the manipulation of terms-of-trade (Bouët and Laborde, 2011). This latter motive is all the more attractive as restrictions on exports apply to products for which the country is a leading world exporter. Contrary to other forms of China's public intervention such as currency manipulation, multiple subsidies and trade protection, fiscal measures targeting exports have been overlooked. While a few recent studies emphasize that export VAT rebates have significant repercussions on the country's export performance (Chandra and Long, 2013; Gourdon et al., 2014) ${ }^{4}$ little is known about the real motives behind the Chinese export tax system.

\footnotetext{
${ }^{1}$ We are grateful to Zhang Yuheng for her research assistance.

*CEPII, email : julien.gourdon@cepii.fr.org

† PSL* - University Paris Dauphine and CEPII, email : stephanie.monjon@dauphine.fr

${ }^{\xi}$ Paris School of Economics (University Paris 1) and CEPII, email : sandra.poncet@univ-paris1.fr

${ }^{3}$ One particularity of the Chinese export VAT-rebate system is that exporters do not necessarily receive a complete refund of the domestic VAT they paid on their inputs. The size of the refund varies widely across commodities, from zero to the full refund of the typical $17 \%$ VAT rate. See Section 2.1.

${ }^{4}$ Relying on firm-level export data for the period 2004-2006, Chandra and Long (2013) found that a one percentage point increase in the VAT-rebate rate is associated with a $13 \%$ increase in exports. Gourdon, Monjon and Poncet (2014) exploited product-level data on export volume over the period 2003-2012 and reported that a one percentage point increase in refunded
} 
This paper is an empirical examination of the determinants of the adjustments in the export VAT-rebate and export tax levels over the last decade. We use VAT-rebate rates and export tax rates at the product level (HS 6-digit level) over the period 2002-12 to investigate how they connect to proxies for official and unofficial intervention motives. This covers justifications given by the public authorities such as those related to the promotion of technology or protection of the environment but also other unstated more strategic motivations pertaining to terms of trade and promotion of some sectors.

Our work builds on the theoretical arguments justifying export taxation (Scholefield and Gaisford, 2007). Theoretically, there are different rationales behind duties on exports (Devarajan et al., 1996; Bonarriva et al., 2009; Scholefield and Gaisford, 2007; Costinot et al., 2013). ${ }^{5}$ Unilateral export tax may improve domestic welfare by raising the world price of a country's exports relative to its imports. This manipulation of terms-of-trade is possible if a country supplies a large share of the world market. Another justification is connected to food security. Public authorities can decrease the consumption price of a good by reorienting domestic supply toward the domestic market (Piermartini, 2004). This may be important when the commodity is an agricultural one and food security is at stake (Bouët and Laborde, 2011). This rationale was frequently used during the food crisis of 2006-2008 to justify the implementation of export taxes and other forms of export restrictions (WTO, 2008). In the same way, export taxation can be used to encourage downstream industries. If the export restriction more specifically discourages exports of raw commodities, this is equivalent to an indirect subsidy to the industries that use these raw products. The domestic price of these products compared to the world price is indeed lowered. Export tax can also be used to stabilize domestic prices for export producers. Lastly, export tax policy is a means of redistributing income from domestic producers to domestic consumers and the public sector.

In this field, empirical work lags behind theoretical work. Empirical studies are relatively rare, partly because of the scarcity of data on fiscal measures. Most existing studies focus on political economy motives (Emran, 2005; McMillan, 2001). Emran (2005) highlighted the role of revenue extraction while McMillan (2001) found empirical evidence that a high export tax is applied when producers cannot easily escape taxation or retaliate against it and when politicians expect little negative repercussions due to higher discount rate, low weight placed on producer surplus and low expected future world prices.

Our objective is more modest. The main contribution of the paper is to examine the consistency between official motives and the actual export taxation structure. We also examine how the priorities of the Chinese government have evolved over time by assessing the explanatory power of a given set of determinants for the export tax and export VAT rebate year by year since 2004. Our work is closest to that of Eisenbarth (2014) who analyses whether China's export VAT-rebates and export taxes are driven by environmental concerns during the period 2006-2009. While our results are consistent with her findings that VAT-rebates rates were adjusted to hamper exports of water and energy intensive products, our work differs in two important dimensions: we do not only focus on environmental motives and we cover a much longer time period, 2004-2012.

\footnotetext{
VAT rate is associated with a $7 \%$ increase in export quantities. They estimated export gains from a one percentage point increase in the export tax to be 5\%. For estimates using a worldwide sample, see Solleder (2013).

${ }^{5}$ Theoretically, incomplete export VAT rebates amount to export taxes and lead to lower exports (Feldstein and Krugman, 1990)
} 
Our analysis of the product structure of export taxation indicates clear support for sophisticated high-technology products, which is in line with the official objectives in the $11^{\text {th }}$ Five-Year Plan (2006-2010). However, the financial crisis in 2008 led authorities to reinforce its support to a variety of industries in which China had a comparative advantage and for which price competitiveness matters, including low technology products such as textiles and ceramics. Our results suggest that the cost of export VAT and the export tax were higher for industries with a higher water pollution intensity and $\mathrm{SO}_{2}$-emissions intensity. More detailed results show that both the instruments were used to curb the exports of water-polluting sectors, while the export VAT rebate was the preferred policy tool for limiting exports of airpolluting products. Both fiscal measures were reinforced from 2007-2008. Our analysis also reveals that the variations in export VAT rebates are consistent with mitigation of trade dispute risks and food security. The possible use of these fiscal tools to give advantage to upstream industries is also confirmed in particular for rare earth products.

The remainder of the paper is organized as follows. The next section describes the Chinese export VAT-rebate and export tax systems and details the changing explanations given by the public authorities for the yearly adjustments of the rates. Section 3 presents the data and our empirical specification. Section 4 discusses the results. Last, Section 5 concludes.

\section{Fiscal policy on exports in China}

\subsection{Presentation of the export VAT rebate and export tax}

\subsubsection{The VAT rebate to exporters}

The People's Republic of China implemented a major tax reform in 1994 by replacing the old industrial and commercial standard tax with a new value-added tax (VAT) (Cui, 2003). VAT applies at a standard rate of 17 percent. The reduced rate of 13 percent applies to basic staples or household necessities such as food, fuel, electricity, books, newspapers and magazines, and agricultural products.

Exporters are granted only partial refund of their VAT cost. A zero rate applies to export goods but VAT paid by the exporters for the inputs bought domestically is not necessarily refunded. Every commodity is assigned a VAT refund rate, which may or may not equal the VAT rate. These refund rates vary widely between sectors and commodities. In 2014, rebate rates were set at $17 \%, 16 \%, 15 \%, 13 \%, 9 \%, 5 \%$ and $0 \%$. A VAT refund lower than the VAT rate imposes a VAT cost on the export sales. It makes it less advantageous for a producer to export a product than to sell it domestically.

The rebate has been used as a policy instrument to encourage or discourage exports, as necessary, and to meet industrial development goals (WTO, 2014). For instance, in 2009, export VAT rebate rates were increased for a large list of products including iron and steel, non-ferrous metals, petrochemicals, electronic and information technology products, and also some light industries such as textiles and clothing. In 2010 by contrast, the VAT rebate on exports of products such as steel, non-ferrous metals processing materials, silver powder, starch, ethanol, pesticides, pharmaceuticals and chemical products, plastic products, rubber products and glass products was eliminated. 
The Chinese VAT-rebate policy on exports is complex and has frequently changed over time, but the method of computing the rebate is rather stable (Ferrantino et al., 2012). According to Circular No.7 (2002), the official formula used to calculate VAT payable for general trade and processing exports with purchased imported materials ${ }^{6}$ is as follows:

$$
\text { VAT payable }=\text { output VAT-Input VAT +NCNR }
$$

Where output VAT=domestic sale*VAT levy rate, input VAT is the VAT paid on domestically purchased inputs and NCNR is a non-creditable and non-refundable amount. NCNR is evaluated as follows:

$$
\mathrm{NCNR}=(\mathrm{X}-\mathrm{BIM}) \times(\text { VAT rate-VAT refund rate })
$$

where $X$ denotes the value of exports and BIM the bonded imported materials.

If VAT payable is positive, the enterprise will have to pay VAT to the tax bureau; if the figure is negative, then the tax bureau will refund it. The amount of refundable VAT is however capped at $(\mathrm{X}-\mathrm{BIM}) \times \mathrm{VAT}$ refund.

\subsubsection{Export tax}

The export tax is an additional source of costs imposed on export sales. However, it targets far fewer products than the export VAT-rebate. This fiscal measure has long been used in China but has been revived since 2007. The number of products targeted at the HS8-level expanded from 91 in 2002 to 359 in 2012 (with a maximum of 369 in 2008).

Export taxes are based on ad valorem rates applied to f.o.b. value of exports (WTO, 2008). The instrument is defined by several rates: a statutory rate and an interim rate. When it exists, the interim is defined only for a limited time and applies by default. It can be higher or lower than the statutory rate. Interim export taxes can also apply to products without a statutory rate. Indeed, the list of the products targeted by the export tax evolves from time to time. For instance, in 2008, three tariff lines (at the HS 8-digit level) were targeted only by a statutory export tax, 68 by statutory and interim taxes and 268 only by an interim tax. Among the lines with statutory and interim taxes, only three had an interim tax higher than the statutory tax.

From 2009, the authorities introduced a special tax on a limited number of products. In 2009, this concerned 35 lines (at the HS 8-digit level), mainly chemical fertilizers and their raw materials.

\subsection{Evolution of export VAT-rebate and taxes since 2000}

The official objectives of the Chinese export VAT-rebate system are very varied, from controlling trade surplus to avoiding conflicts with foreign trade partners, increasing government revenue or guiding the growth of certain industries. By contrast, the export tax has been justified more specifically to limit the exports of environmentally damaging products or to control inflation during the $2006-2008$ food crises. In the following, we rapidly present

\footnotetext{
${ }^{6}$ The export VAT refund refers to the typical export VAT policy called "exempt, credit, and refund" (or "refund after collection"). By contrast, the "no collection and no refund" policy applies to processing trade with supplied inputs. In this type of trade, the firm undertakes processing or assembly work on materials it does not own. Even if the exporter pays VAT on local purchases, there is no entitlement to any export refund.
} 
the different policy objectives that have been stated to explain the changing rates of each instrument in recent years.

\subsubsection{Export VAT-refund}

In the 1980s, Chinese authorities used export VAT refund to avoid exports of agriculture and raw material products (Wang, 2011). With the increasing role of exports in the national economy, export VAT refunds were frequently adjusted to address different types of economic issues. The $10^{\text {th }}$ and $11^{\text {th }}$ Five Year Plans (2001-2005 and 2006-2010 respectively) clearly state that the objective of the Chinese government is to shift China's export structure towards more value-added and high technology products. Energy and environmental problems also appeared in the $10^{\text {th }}$ Five-Year Plan. Since 2004 the Chinese government has lowered and even abolished export tax rebates for some energy-intensive, heavily-polluting and resource-based products. It also banned or limited the processing trade in some of those products, and encouraged import and export enterprises to keep up with the world's advanced environmental standards. ${ }^{7}$

The changes in the refund rates were also motivated by other objectives. For instance, the boom in the Chinese trade surplus raised concerns among its trade partners in the WTO. China significantly decreased the refund rates of several thousands of products in 2007 in order to keep its trade surplus under control and to avoid trade disputes (Yan, 2010). From 2008, the global economic crisis led the authorities to raise the export VAT refund rates on a large number of commodities while continuing to target high value-added and high technology products (Wang, 2011). Labor-intensive goods also benefited from these changes.

Figure 1 depicts the ratio between the VAT rebate and VAT rates over the period 2002-2012. The VAT rebate share declined continuously from 2002, before rebounding in 2009 in reaction to the international economic crisis. In 2008, eligible exporters could get back roughly $53 \%$ of their VAT cost, down from $84 \%$ in 2002 . This proportion rose back to $63 \%$ in 2009 and has remained there since.

\subsubsection{Export Tax in China}

The export tax rates have been revised regularly with frequent adjustments in the list of products subject this fiscal measure (WTO, 2008). Figure 2 depicts the evolution of the number of products (HS8-digit) targeted by an export tax and, among these products, the share to which a positive export tax applies. The upward trend indicates a more intensive use of this fiscal measure during the last decade.

Export taxes have been used by many developing countries in recent decades (Kim, 2010). Interestingly, they seldom mention environmental problems to justify export taxes. In China, however, export taxation has been used officially by the public authorities to limit exportations of products that cause pollution and consume large amounts of natural resources or energy, more particularly since the 11th Five-Year Plan.

\footnotetext{
${ }^{7}$ See the Chinese Government's Official Web Portal: http://www.gov.cn/english/official/2011-12/07/content_2014019_7.htm.
} 
Export taxes were also used on food exports to control inflation during the 2006-2008 food crises (Lohmar and Gale 2008). Indeed, food prices in China increased in 2006 and in 2007. As a result, China withdrew export VAT refund and introduced temporary export taxes on grain and flour with the aim of reducing grain exports and cooling domestic grain prices. Fertilizers were also targeted. A shortage of fertilizers appeared in China in 2006. In reaction, Chinese authorities implemented a series of measures; fertilizers in particular were targeted by a special tax in addition to the export tax (Wang, 2011).

Export taxes were also modified to mitigate the negative effects of the global crisis on Chinese exports. The authorities then decreased, or even removed, the taxes on some products, like wheat, rice, steel, and some non-ferrous metals. But the taxes were reintroduced later.

\section{Data and empirical strategy}

\subsection{Data on VAT and export taxes}

Our variables of interest here are VAT, export VAT-rebate and export tax rates. The VAT and the export VAT-rebate rates are taken from the Etax yearbooks of Chinese Customs at the tariff-line level (HS 8-digit or more disaggregated levels). Export tax information comes from the websites of the General Administration of Customs of the People's Republic of China (www.customs.gov.cn) and the Ministry of Finance of the People's Republic of China (www.gss.mof.gov.cn). This rate includes the special tax (from 2009) when applicable.

We aggregate the data to the HS6 level using the yearly average of these rates which yields a panel of 5,878 products over 2002-12. We account for the change in the HS nomenclature in 2007 and 2012 by dropping products for which the HS code changed from that in 2002. These adjustments eliminate 531 HS6 products representing around 13\% of yearly exports. Overall, our final sample includes observations on 4,901 HS6 products, which represent roughly $82 \%$ of Chinese total exports over the period 2002-2012.

\subsection{Different classifications of products}

Our objective was to check whether the changes in the export VAT-rebate and export tax rates relate to the official motives stated by the public authorities, in particular the focus on high value-added and high-technology products, environmentally damaging goods and agricultural goods. Building on the theoretical literature, we also examine the possible use by China of these fiscal tools to improve its terms of trade, when it supplies an important share of the world market, or to implement an indirect subsidy to downstream industries. We present the different classifications used to characterize the products. Most of them are at the HS6-digit level.

\section{High value-added and high technology products}

There is no simple single classification for these types of products. We first consider the sophistication index proposed by Hausmann et al. (2007). This indicator measures the implied productivity of a product and is constructed by taking a weighted average of the percapita GDPs of the countries exporting the product, where the weights reflect the revealed comparative advantage of each country in that product. More sophisticated products refer to 
capital- and skill-intensive products, high-technology products, and are usually considered as belonging to the area of specialization of more developed countries. Measures of HS6 product-level sophistication, henceforth PRODY, for 1997 are taken from the CEPII. ${ }^{8}$

In the second step, we use OECD's classification, which provides a comprehensive and detailed list of the most technology-intensive products (Hatzichronoglou, 1997). Medium- and high-technology categories are provided. The classification is based on the R\&D intensity, whether direct or indirect, of each product (evaluated at the HS 6-digit level since 1994).

\section{Environmentally damaging products}

The statements by the Chinese authorities that relate the changes in VAT rebates and export taxes to environmental concerns are generally vague. The recent Five-Year Plans nevertheless gave explicit and precise objectives for a limited number of pollutants. In the $10^{\text {th }}$ and $11^{\text {th }}$ Five-Year Plan (2001-2005, and 2006-2010 respectively), only the sulfur dioxide $\left(\mathrm{SO}_{2}\right)$ and chemical oxygen demand (COD) were targeted (OECD, 2013). At the end of the $10^{\text {th }}$ Five-Year Plan, the reduction objectives for $\mathrm{SO}_{2}$ and $\mathrm{COD}$ were not attained. In contrast, marked progress was made during the $11^{\text {th }}$ Five-Year Plan. In addition to $\mathrm{SO}_{2}$ and COD, the $12^{\text {th }}$ Five-Year Plan (2011-2015) added several new pollutants with binding objectives: nitrous oxide emissions in air and ammonia nitrogen releases to water. Moreover, for the first time, China adopted a target of decreasing its $\mathrm{CO}_{2}$ emissions, although expressed per GDP unit.

Data on the pollution intensity of activities are scarce in China. Information is highly aggregated, enabling differentiation between 25 sectors at best (Hering and Poncet, 2014). We opted for the more detailed data available from the World Bank's Industrial Pollution Projection System (Hettige et al., 1995). This database provides information on different types of pollutants per value-added unit and pollution output intensities per medium (air/land/water) at the 4-digit of the Standard Industrial Classification (SIC) ${ }^{9}$. It is constructed using US statistics in 1987. In our models, we include the sectoral $\mathrm{SO}_{2}$ emissions and waterpollution intensities, which have been explicitly targeted by the Chinese authorities. While emission levels between US and Chinese industries differ, we are concerned with relative rather than absolute levels of emissions. The use of US-based indices of pollution intensity by sector relies on the hypothesis of a technological component to pollution intensity which is common to firms in the US and in China. Moreover, the United States have advanced technology, so that the variation in the pollution intensity across US sectors should reflect the technology-specific component of pollution emissions. In addition, pollution indicators based on US data can be seen as exogenous to fiscal policies in China. These indices are likely to take different values if they are calculated on Chinese data exactly as they reflect the fact that firms strategically adjust their emissions in response to the taxes. We use the concordance table between SIC sectors and HS6 products from the World Bank's World Integrated Trade Solution (WITS) platform.

In the second step, we opted for an indicator identifying the energy-intensive sectors. Irrespective of the nature of pollution, the "usual suspects" are usually the same because they consume large quantities of fossil fuels. ${ }^{10}$ Information on the energy consumption of the manufacturing sectors is available from the US Energy Information Agency. In particular, EIA

\footnotetext{
${ }^{8} \mathrm{http}: / /$ www.cepii.fr/cepii/fr/bdd_modele/presentation.asp?id=10. The index is developed using the BACl world trade dataset.

9 At 4-digit level, the SIC distinguishes 218 industrial sectors.

${ }^{10}$ See Mani \& Wheeler (1998), for instance.
} 
(2005) lists the most energy-intensive sub-sectors at the 4-digit of the North American Industry Classification (NAICS). We constructed a dummy identifying the 73 most energyintensive products. We used the concordance table between NAICS and HS6 products from the (WITS) platform.

\section{Food products}

The classification by Broad Economic Categories (BEC) developed by United Nations Statistics Division makes it possible to distinguish products according to large economic classes of commodities, highlighting in particular food and beverages and industrial supplies. The information is given at HS 6-digit level. The classification makes it possible to identify primary and processed products and whether food and beverages are mainly destined for industrial or household consumption (UN, 2002). This classification allows us to see if the export fiscal tools were used not only to limit the impact of the food crisis on the Chinese population but also to promote downstream industries.

\section{Risk of trade conflicts}

It is likely that the risks of trade conflicts emerge when China's share of the world market increases quickly and significantly. We consequently included in the model the growth, over two years, of the Chinese world market share at the HS 6-digit level. The world export share of China for each HS6 product comes from the WITS platform.

\section{Other determinants}

Our aim was to test other possible causes of adjustments in rates of rebate or tax. The first motive is to move up the value chain: a higher export VAT cost for raw materials depresses the price of raw materials, thereby subsidizing upstream industries. Trade partners have strongly criticized China for its restrictions on raw materials and rare earths. Some have requested formal dispute settlement procedures in the WTO. ${ }^{11}$ We use the BEC classification to identify primary agricultural and industrial goods mainly for industry (UN, 2002). We also specifically examine the case of rare earths, which play a key role in the production process of important high value-added products. WTO's classification was used to identify these elements.

A second motive is manipulating terms of trade. When a country supplies a significant share of the world market in a commodity, the limitation of its exports raises its world price, hence improving its terms of trade. In a Ricardian general-equilibrium framework, Costinot et al (2013) show that optimal export taxes should increase with the country's comparative advantage. This reflects "the fact that countries have more room to manipulate world prices in their comparative-advantage sectors" (Costinot et al, 2013). We rely on a measure of the revealed comparative advantage (RCA) from the WITS platform. It is generated at the HS 6digit level and is defined as the ratio of the share of a given product in the country's total exports over the share of that product in the total world exports.

\footnotetext{
${ }^{11}$ Disputes DS394, DS39 and DS398 : China - Measures Related to the Exportation of Various Raw Materials at the request of United States, EU and Mexico in June and August 2009. Disputes DS431, DS432 and DS433: China - Measures Related to the Exportation of Rare Earths, Tungsten and Molybdenum at the request of by United States, EU and Japan in March 2012.
} 
Table 1 presents the different classifications, the type of the variables used in the regressions and the sources of the information. Table 2 shows some summary statistics for the sample used in the regressions. The standard VAT rate of $17 \%$ applies to roughly $95 \%$ of the HS6 products in our sample. Given that the same VAT rate is not applied to all the products, we use the difference between the VAT and the VAT-rebate rates which represents the VAT cost incurred by the exporters, hence the export VAT cost. The higher this difference, the greater the VAT cost for exporters. If the statements made by the Chinese authorities are confirmed, we should find a negative relationship between the export VAT cost and the products the government wishes to promote, while the relationship should be positive for environment-damaging products. Table 2 suggests that the export VAT cost is higher for raw materials, in particular rare earths, and energy-intensive products.

Table 3 presents statistics on the coverage of the two fiscal instruments over time for a selection of product categories. While almost all the products had some degree of VAT refund in 2002, the number of products with zero VAT rebate rose sharply in the period 20042006. A second round of denial of VAT reimbursement occurred in 2011-12 for metals and chemicals. The coverage of export taxes was much more limited but expanded sharply in 2007. Table 3 shows that a high proportion of products to which an export tax applies, receive zero export VAT refund (i.e. the category Both).

\subsection{Empirical strategy}

Our objective is to identify the main features that characterize products with high degree of export taxation in China. We looked at two different dependent variables: the export VAT cost, defined as the VAT rate minus the export VAT-rebate rate, and the export tax.

Our empirical approach consists in estimating the following equation on our panel of HS6 products over the period 2003-2012.

$$
Y_{k, t}=\beta_{1} X_{k}+\beta_{2} Z_{k, t-1}+\delta_{s, t}+\varepsilon_{k, t}
$$

where the explained variable $Y_{k, t}$ is in turn, the export VAT cost (in \%) and the export tax (in $\%)$. In Equation (1), $\delta_{s, t}$ correspond to sector-year fixed effects and $\varepsilon_{k t}$ is an idiosyncratic error term.

Sectors are defined according to the Chinese classification. ${ }^{12}$ We rely on the 1-digit classification and include 80 time-varying sector dummies (for 8 sectors over 10 years) so as to limit the risk of omitted variables that could bias our estimates. We report the results with standard errors clustered at the 2-digit sector as this tends to give more conservative (larger) estimates for standard errors (Wooldridge, 2003). The product level explanatory variables are of two types: time invariant $(X)$ and time-varying $(Z)$. For the latter group, we lag variables by one year so as to deal with potential endogeneity problems.

To explore whether the export taxation motivations evolved over time, we estimated Equation (1) year by year (the subscript t no longer applies) and studied how coefficients on the explanatory variables varied over time.

Lastly, ANOVA estimations were performed to evaluate which variables explain the most variance of our dependent variables. This method evaluates the range of the variance in a dependent variable attributable to each explanatory variable.

\footnotetext{
${ }^{12}$ The correspondence table between Chinese (GB/T) industry codes and HS codes is taken from Upward et al. (2013).
} 


\section{Average results}

Table 4 presents the results for export VAT cost and Table 5 for export tax over the period 2004-2012. ${ }^{13}$ Columns (1) focus on the main explanations given in the statements made by public authorities: encouragement of exports from sectors producing high value-added and high-technology products, limitation of exports from polluting sectors, mitigation of the risk of trade disputes and food security. Column (2) adds proxies for other possible motives, namely favoring downstream sectors and improving the terms of trade. It hence includes two dummy variables to capture possible restrictions applied to raw materials and rare earths and an index of revealed comparative advantage. In columns (3) to (5), we test the robustness of the two first columns: we rely on alternative proxies or further disaggregate our indicators.

Column 6 presents the model used to examine changed in motives over the period concerned.

The results displayed in column (1) of Table 4 are in line with the explanations given by the Chinese authorities. During the period, higher export VAT cost targeted the $\mathrm{SO}_{2}$-emissive products and the products for which the world market share has increased. ${ }^{14}$ On the other hand, more sophisticated products benefited from a more favorable export VAT rebate. Water-pollution intensity has the expected sign but is not significant ${ }^{15}$. Last the dummy for food and beverage goods intended to capture the "food security" argument enters with a positive but insignificant sign.

Column (2) adds binary variables identifying inputs for industry and rare earths as well as a measure of revealed comparative advantage. It constitutes our benchmark model. Most of the determinants in Column (1) remained significant but Column (2) reveals that other motives may explain the variations in the export VAT rebate. Raw materials used by industry and rare earths are characterized by a higher export VAT cost. The revealed comparative advantage indicator is significant but enters negatively, which contrasts with the terms of trade manipulation argument. It may however indicate a greater capacity of producers operating in the most important sectors for the Chinese export performance to lobby to be granted a lower fiscal burden. After those additional indicators are included, our measure of water pollution intensity becomes significant at the $10 \%$ confidence level. Finding a positive and significant association between pollution intensity and export VAT cost will prove robust in the latter more demanding specifications. This result is in line with those of Eisenbarth (2014). Lastly, the indicator identifying the food and beverages used mainly for households' consumption is now significant. This result will be confirmed as well in the following columns.

Columns (3) to (6) test the robustness of our benchmark results. Column (3) introduces an OECD classification more focused on technology than the sophistication indices. Column (4) replaces the $\mathrm{SO}_{2}$ emissions intensity by a dummy identifying the most energy-intensive sectors. Column (5) disaggregates the food and beverages for households between primary and processed products, on the one hand, and the primary goods for industry between agricultural and industrial products on the other.

In a nutshell, the benchmark results are confirmed. Public support for technology-intensive goods, in particular those with high-technological contents, is confirmed. The most energy-

\footnotetext{
${ }^{13}$ Our sample covers the period 2002-2012.

${ }^{14}$ Growth was evaluated between $\mathrm{t}-2$ and $\mathrm{t}-1$. We obtained the same result for growth between $\mathrm{t}-3$ and $\mathrm{t}-2$ and $\mathrm{t}-3$ and $\mathrm{t}-1$.

${ }^{15}$ Significant at $12 \%$
} 
intensive products support higher export VAT cost. Column (5) shows that all the disaggregated indicators are positive and significant. More precisely, the primary industrial products are more impacted by low export VAT refund than the primary agricultural ones. These results thus support the "food security" argument: due to lower export VAT rebates, the Chinese population has had access to cheaper food products. But the possible use of the fiscal tool to support downstream sectors, in particular in non-agro industries, is also confirmed.

Column 6 presents the variables we kept to examine changes in the determinants developed in Part 5 over time.

Table 5 follows the logic of Table 4 and presents the results for the export tax. Qualitatively, the results are relatively close to those obtained for the export VAT rebates, except that fewer indicators are significant. As apparent in Column (1), lower export tax applies to sophisticated products. By contrast, products responsible for water pollution incurred higher tax when exported. These results remain valid in other columns. The growth of the world market share has the expected positive association with export tax but it is only significant in Column (1). In Column (2), the dummies for raw products for industries and for rare earths are positive and significant, suggesting that export tax was used to promote exports of downstream industries. Lastly, like in Table 4, the revealed comparative advantage indicator is significant but negative. The public authorities thus supported the exports of goods featuring stronger comparative advantage. Section 5 will reveal the specific role played by this indicator.

These first results thus support the explanations given by the Chinese authorities to justify the frequent variations in the export VAT rebates and export taxes. They also reveal the possible use of these fiscal instruments to promote downstream industries. Both fiscal tools are used to encourage exports of more value-added and high technology products, to discourage exports of water-polluting products and possibly to indirectly subsidize downstream industries. Further, the export VAT rebate appears to follow other specific purposes, notably to limit exports of air polluting sectors, mitigate trade dispute risks, and promote food security.

\section{Have the motives changed over the study period?}

Tables 6 and 7 report the results, year by year, of the export VAT cost and the export tax respectively for the period 2004-2012. They point to major changes in the importance of the different motives over time. For the export tax, the model performs relatively poorly prior to 2007 , certainly due to the very few products targeted by the measure before that year. After 2007, clear patterns emerge.

The results reveal increasing support for sophisticated products over the period, in particular from 2007 on. Both the VAT rebate and the export tax were applied for this purpose. It is consistent with the objectives stated in the 11th Five-Year Plan (2006-2010) to shift China's export structure towards more value-added and high technology products. Stronger efforts were made in 2009 and 2010, certainly to mitigate the negative impacts of the economic crisis. 
Products featuring stronger comparative advantage were promoted only from 2009 with export VAT rebate ${ }^{16}$, suggesting that support aimed to mitigate the economic crisis. During this period, the Chinese authorities actually promoted all kinds of key sectors, including textile and ceramics, with low added value but for which price competitiveness matters. Since then, these supporting measures have been maintained.

Since 2005, polluting products have continuously been targeted by a higher fiscal burden when they are exported. Export VAT rebates are more used for air pollution, while export taxes focus rather on water pollution. From 2007-2008, the fiscal burden incurred by the exporters of these products increased significantly. This period corresponds to the 11th FiveYear Plan where marked progress was made in reducing some pollutants, after the failure to attain the environmental objectives of the 10th Five-Year Plan.

The indicator of world market share growth became significant from 2008 to 2011. During the 2000s, there was a marked escalation in concerns about China's trade surplus (Woo and Xiao, 2007). Conscious of the risk of trade disputes, public authorities modified the fiscal measures targeting exports to limit trade surpluses. ${ }^{17}$ This explains the increasing fiscal pressure from 2008 on for the products for which China recorded significant rise of its world market share, while the world economic crisis exploded. As a consequence, measures to limit the damage caused by the crisis did not target those products. This suggests that Chinese authorities answered the concerns of their trade partners, while improving their terms of trade on these markets.

Lower export VAT rebates were applied to agricultural products used mainly for household consumption during the entire period considered. Nevertheless, the difference was more marked from 2008 on.

The association between the export VAT cost and the dummy for raw materials for industry is positive and increases over the period to stabilize in 2009. The evolution was similar for the export tax. These results are consistent with the increasing determination of public authorities to move up the value chain. This objective is achieved by promoting upstream sectors, leading to unequal treatment of domestic and foreign firms. The results are similar for rare earths.

Figures 3 and 4 present the results of ANOVA estimations. This reveals whether the different motives have evolved over the period. We do not comment all the variables but focus on the most significant results.

First, for the export VAT rebate, the importance of the different determinants has evolved over the period. Two indicators have kept the main explanatory power: $\mathrm{SO}_{2}$ emissions products and primary foods for industry. The last determinant was particularly important at the beginning of the period. The importance of the environmental motivation, based on $\mathrm{SO}_{2}$ emissions, grew over the period as an explanatory force of the fiscal burden. Its explanatory power rose from around 10 percent in 2004 to roughly 50 percent in 2008 to stabilize at 27 percent at the end of the period.

\footnotetext{
${ }^{16}$ For the export tax, this indicator was only significant in 2010.

17 "On June 19, 2007, in an attempt to demonstrate China's good faith by making efforts to keep trade surplus under control, the Ministry of Finance (MOF) and the State Administration of Taxation (SAT) jointly issued Circular No. 90 (which became effective on July 1,2007) which profoundly modified the VAT refunding scheme on exports. [...] As a result, VAT refund rates were reduced by between 2 and 8 percentage points on 2,268 commodities deemed likely to trigger trade disputes" (Wang, 2011).
} 
As can be seen in Table 7, our model does not predict export tax over the period 2003-2006 very well, mostly due to the few products to which export tax applied before 2007 . Logically the ANOVA computations focus on the period 2007-2012 for this instrument. The results are reported in Table 9 and Figure 4. They show that limitation of water-polluting products exports has played a key role in determining the export tax rates since 2008.

\section{Conclusion}

This paper investigates the motives behind China's fiscal policy targeting exports. It relies on detailed data at the product level (HS 6 digit) over the period 2002-2012. We analyzed two major export taxation instruments: export tax and export VAT rebate. Our results suggest that while pursuing many objectives simultaneously, Chinese policy used both instruments in a complementary way with the aim of achieving their industrial policy and strategic objectives. Some are officially stated such as promoting technology or environmental protection, but others do not appear in official documents, such as subsidizing downstream sectors. We also observed that China used those instruments in a dynamic way to address temporary shocks, for example to temper food price rises or to support strategic sectors sensitive to price competitiveness in the middle of the financial crisis. 


\section{References}

Bonarriva, Joanna, Michelle Koscielski and Edward Wilson, 2009, Export Controls: An Overview of their Use, Economic Effects, and Treatment in the Global Trading System, US International Trade Commission, Office of Industries, ID-23, August.

Bouët, Antoine, and David Laborde, 2011, Food Crisis and Export Taxation: The Cost of Non-Cooperative Trade Policies, Review of World Economics, 148(1), 209-233.

Chandra, Piyush and Cheryl Long, 2013, VAT rebates and export performance in China: Firm-level evidence, Journal of Public Economics 102, 13-22.

Chen, Chien-Hsun, Mai, Chao-Cheng, Yu, Hui-Chuan, 2006, The effect of export tax rebates on export performance: theory and evidence from China, China Economic Review, 17(2), 226-235.

Circular No.7, 2002, Notice on Further Implementing the "Exemption-Credit-Refund" System of Export Tax Rebate, issued jointly by the Finance Ministry and the State Administration of Taxation in China, October.

Costinot, Arnaud, Dave Donaldson, Jonathan Vogel and Ivan Werning, 2013, Comparative advantage and optimal trade policy, NBER Working Paper, 19689.

Cui, Zhiyuan, 2003, China's Export Tax Rebate Policy, China: An International Journal, 1(2), 339-349.

Devarajan, Shantayanan, Delfin Go, Maurice Schiff and Sehaput Suthiwart-Narueput, 1996, The Whys and Why Nots of Export Taxation, The World Bank, Policy Research Working Paper, November.

Ebenstein, Avraham, 2012, "The Consequences of Industrialization: Evidence from Water Pollution and Digestive Cancers in China" Review of Economics and Statistics 94 (1): 186-201

Eisenbarth, Sabrina, 2014. Is Chinese Trade Policy Motivated by Environmental Concerns? An Empirical Analysis, mimeo, University if Nottingham.

Emran, M. Shahe, 2005, "Revenue-increasing and Welfare-enhancing Reform of Taxes on Exports." Journal of Development Economics 77 (1): 277-292

Energy Information Administration (EIA), 2005, Energy-Related Carbon Dioxide Emissions in U.S. Manufacturing, DOE/EIA-0573(2005).

Evenett, Simon J., Johannes Fritz and Yang Chun Jing, 2012, "Beyond Dollar Exchange-rate Targeting: China's Crisis-era Export Management Regime", Oxford Review of Economic Policy, 28(2), 284-300.

Feldstein, Martin, and Paul Krugman, 1990, International trade effects of value-added tax, in: Razin, A., Slemrod, J. (Eds.), Taxation in the Global Economy. University of Chicago Press, 263-282.

Ferrantino, Michael J., Xuepeng Liu and Zhi Wang, 2012, Evasion behaviors of exporters and importers: Evidence from the U.S.-China trade data discrepancy, Journal of International Economics, 86, 141-157.

Gourdon Julien, Stéphanie Monjon and Sandra Poncet, 2014, Incomplete VAT Rebates to Exporters: How Do They Affect China's Export Performance?, CEPII Working Paper, $\mathrm{N}^{\circ} 2014-05$, February.

Hatzichronoglou, Thomas, 1997, "Revision of the High-Technology Sector and Product Classification", OECD Science, Technology and Industry Working Papers, No. 1997/02, OECD Publishing, Paris. 
Hausmann, Ricardo, Jason Hwang and Dani Rodrik, 2007, What you export matters, Journal of Economic Growth 12 (1), 1-25.

Hering, Laura and Sandra Poncet, 2014, "Environmental policy and exports: Evidence from Chinese cities", Journal of Environmental Economics and Management, forthcoming.

Hettige, Hemamala, Paul Martin, Manjula Singh and David Wheeler, 1995, "IPPS: The Industrial Pollution Projection System," World Bank, Policy Research Department Working Paper, February

Kim, Jeonghoi 2010, "Recent Trends in Export Restrictions", OECD Trade Policy Papers, No. 101, OECD Publishing.

Koopman Robert, Zhi Wang, and Shang-Jin Wei, 2011. How Much of Chinese Exports is Really Made in China? Assessing Domestic Value-Added When Processing Trade is Pervasive, NBER Working Paper No. 14109, June 2008, Revised December 2011.

Lohmar, B. and F. Gale, 2008, Who Will China Feed?, Amber Waves 6(3): 10-15, Economic Research Service/USDA.

Mani, Muthukumara S., and David Wheeler. 1998. In Search of Pollution Havens? Dirty Industry in the World Economy, 1960-1995. The Journal of Environment and Development 7 (3), September: 215-247.

McMillan, Margaret. 2001, "Why Kill the Golden Goose? A Political-Economy Model of Export Taxation." Review of Economics and Statistics 83 (1) (February 1): 170-184.

Piermartini, Roberta, 2004, "The Role of Export Taxes in The Field of Primary Commodities", WTO Discussion Papers, Geneva, Switzerland.

OECD, 2013, OECD Economic Surveys: China, Paris, March.

Scholefield Ryan and James Gaisford, 2007, "Export taxes : how they work and why they are used" chapter in Handbook on international trade policy, p. 237-247. Cheltenham: Elgar.

Solleder, Olga, 2013. "Trade Effects of Export Taxes," IHEID Working Papers 08-2013, Economics Section, The Graduate Institute of International Studies,

United Nations (UN), 2002, Classification by Broad Economic Categories, Department of Economic and Social Affairs, Statistics Division, ST/ESA/STAT/SER.M/53/Rev., UN Publication, New York.

Upward, Richard, Zheng Wanga and Jinghai Zheng, 2013. "Weighing Chinaaŕs export basket: The domestic content and technology intensity of Chinese exports," Journal of Comparative Economics, Elsevier, vol. 41(2), pages 527-543.

Wang, Xin, 2011, An Economic and Political Assessment of Carbon Pricing Policies in China, PhD dissertation.

Woo, Wing Thye, and Geng Xiao, 2007. Facing Protectionism Generated by Trade Disputes: China's Post-WTO Blues, Brookings Global Economy and Development, Global Economy and Development working paper 13, November.

Wooldridge, Jeffrey M. 2003, "Cluster-Sample Methods in Applied Econometrics," American Economic Review 93, 133-138

World Trade Organization (WTO), 2014, Trade Policy Review, China, Report by the secretariat, WT/TPR/S/300, 27 May.

World Trade Organization (WTO), 2012, Trade Policy Review, China, Report by the secretariat, WT/TPR/S/264, 8 May.

World Trade Organization (WTO), 2008, Trade Policy Review: China, Report by the Secretariat, WT/TPR/S/199, 16 April. 
Yan, Xu, 2010, Reforming Value Added Tax in Mainland China: A Comparison with the EU, Revenue Law Journal: Vol. 20 (1), Article 4. 
Figure 1: VAT refund rate over 2002-2011

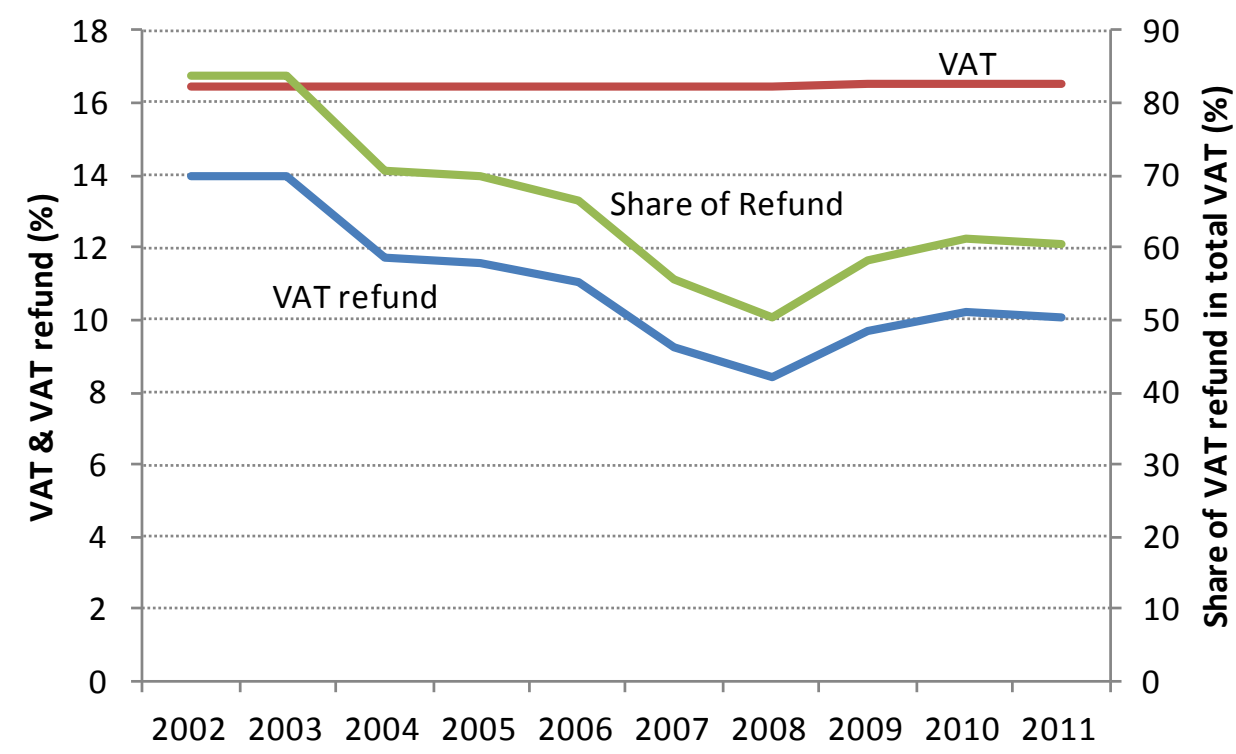

Note: Computations use the simple average over all products.

Figure 2: HS8 lines targeted by export tax and share of HS8 lines with zero export tax

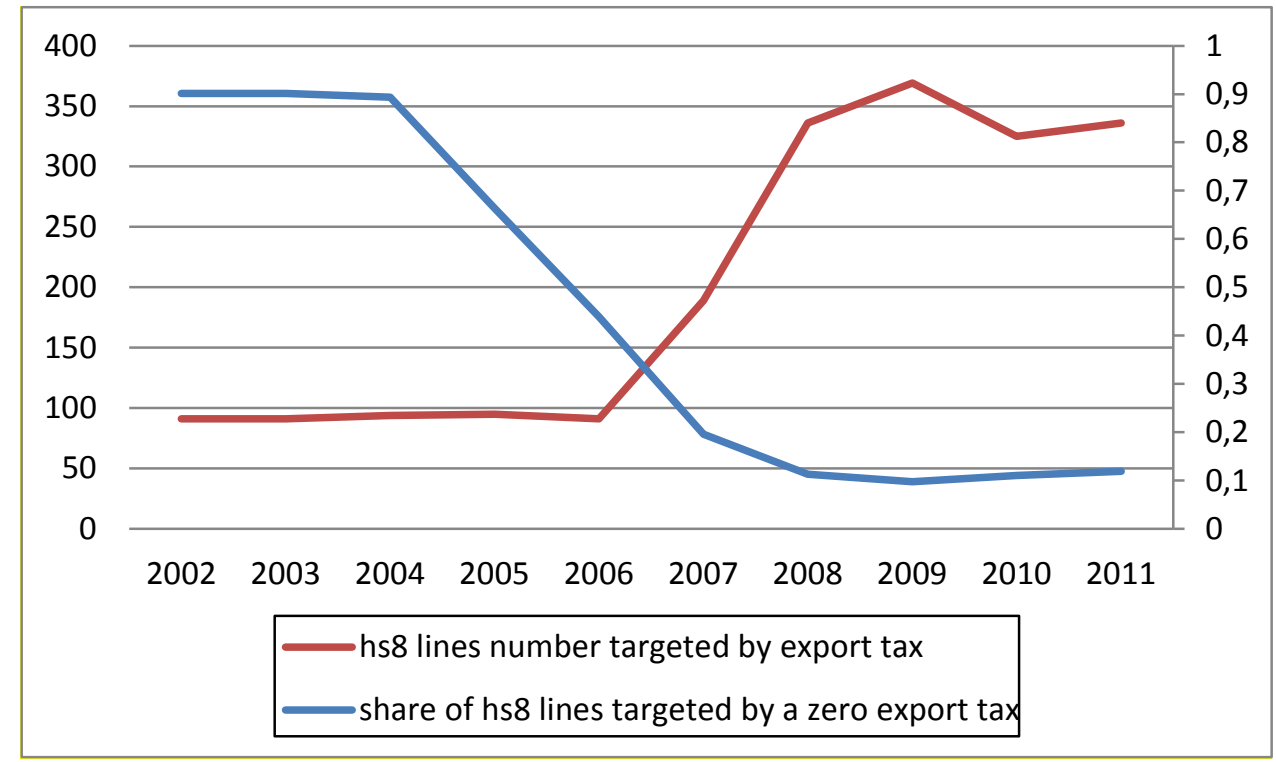

Note: For example, in 2011, 336 HS8 lines were targeted by an export tax, but the statutory rate has been replaced by a zero interim rate for $40(12 \%)$ of the HS8 lines. 
Table 1: Characterization of the products

\begin{tabular}{|c|c|c|c|}
\hline & $\begin{array}{l}\text { Type of } \\
\text { variable }\end{array}$ & Transformation & Drawn from \\
\hline \multicolumn{4}{|l|}{$\begin{array}{l}\text { High value-added and } \\
\text { technology products }\end{array}$} \\
\hline Sophistication & $\begin{array}{c}\text { Continuous } \\
\text { based on } \\
\text { data from } \\
1997 \\
\end{array}$ & $\operatorname{Ln}$ & Jarreau and Poncet (2009) \\
\hline Technological intensity & $\begin{array}{c}\text { Binary } \\
\text { variable }\end{array}$ & & $\begin{array}{l}\text { OECD's classification } \\
\text { Hatzichronoglou (1997) }\end{array}$ \\
\hline \multicolumn{4}{|l|}{$\begin{array}{l}\text { Environmental } \\
\text { concerns }\end{array}$} \\
\hline $\begin{array}{l}\mathrm{SO}_{2} \text {-emissions and } \\
\text { water-discharges } \\
\text { intensities }\end{array}$ & $\begin{array}{c}\text { Continuous } \\
\text { based on } \\
\text { data from } \\
1987 \\
\end{array}$ & Ln & $\begin{array}{l}\text { World Bank's IPPS } \\
\text { Hettige et al. (1995) }\end{array}$ \\
\hline Energy Intensive sectors & $\begin{array}{c}\text { Binary } \\
\text { variable }\end{array}$ & & EIA (2005) \\
\hline \multicolumn{4}{|l|}{ Trade dispute risks } \\
\hline $\begin{array}{l}\text { Growth world market } \\
\text { share }\end{array}$ & $\begin{array}{l}\text { Continuous } \\
\text { and } \\
\text { evaluated } \\
\text { each year }\end{array}$ & Lagged In & World Bank's WITS \\
\hline \multicolumn{4}{|l|}{ Food crisis } \\
\hline $\begin{array}{l}\text { Food \& beverage } \\
\text { products for households }\end{array}$ & $\begin{array}{c}\text { Binary } \\
\text { variable }\end{array}$ & & $\begin{array}{c}\text { Classification by BEC } \\
\text { UN (2005) }\end{array}$ \\
\hline \multicolumn{4}{|l|}{ Other determinants } \\
\hline $\begin{array}{l}\text { Primary goods for } \\
\text { industry }\end{array}$ & $\begin{array}{c}\text { Binary } \\
\text { variable }\end{array}$ & & $\begin{array}{c}\text { Classification by BEC } \\
\text { UN (2005) }\end{array}$ \\
\hline Rare Earth & $\begin{array}{c}\text { Binary } \\
\text { variable }\end{array}$ & & Classification by WTO \\
\hline $\begin{array}{l}\text { Revealed comparative } \\
\text { advantage }\end{array}$ & $\begin{array}{l}\text { Continuous } \\
\text { and } \\
\text { evaluated } \\
\text { each year }\end{array}$ & Lagged In & World Bank's WITS \\
\hline
\end{tabular}


Table 2: Summary statistics

\begin{tabular}{|c|c|c|c|c|c|}
\hline Variable & Observations & Mean & $\begin{array}{l}\text { Std. } \\
\text { Dev. }\end{array}$ & Min. & Max. \\
\hline VAT rate (\%) & 49,932 & 16.52 & 1.24 & 13 & 17 \\
\hline $\begin{array}{l}\text { VAT rebate } \\
\text { rate }(\%)\end{array}$ & 49,932 & 11 & 5.17 & 0 & 17 \\
\hline $\begin{array}{l}\text { VAT rate - } \\
\text { VAT rebate } \\
\text { rate }(\%)\end{array}$ & 49,932 & 5.5 & 4.86 & 0 & 17 \\
\hline Export rate (\%) & $\begin{array}{c}1,321 \\
(\text { export rate }>0)\end{array}$ & 16.43 & 15.96 & 2 & 106.25 \\
\hline \multirow{6}{*}{$\begin{array}{l}\text { VAT rate - } \\
\text { VAT rebate } \\
\text { rate (\%) }\end{array}$} & $\begin{array}{c}14,401 \\
\text { (medium-technology products) }\end{array}$ & 4.53 & 4.66 & 0 & 17 \\
\hline & $\begin{array}{c}3,086 \\
\text { (high-technology products) }\end{array}$ & 2.30 & 2.12 & 0 & 13.75 \\
\hline & $\begin{array}{c}17,222 \\
\text { (energy-intensive products) }\end{array}$ & 7.80 & 5.28 & 0 & 17 \\
\hline & $\begin{array}{l}3833 \\
\text { (Food \& beverages for } \\
\text { households) }\end{array}$ & 6.25 & 2.69 & 0 & 17 \\
\hline & $\begin{array}{l}2879 \\
\text { (primary products for industry) }\end{array}$ & 9.80 & 5.18 & 0 & 17 \\
\hline & $\begin{array}{c}231 \\
\text { (Rare earths) }\end{array}$ & 12.25 & 6.00 & 0 & 17 \\
\hline
\end{tabular}

Note: The statistics are based on the initial sample of 49,932 observations. VAT rates, VAT rebate rates, the difference between the VAT and rebate rates and export taxes are measured as percentages. 
Table 3: HS6 products targeted by export tax and by zero VAT rebate

Chapter (products) 20022003200420052006200720082009201020112012

\begin{tabular}{|c|c|c|c|c|c|c|c|c|c|c|c|c|}
\hline \multirow{3}{*}{ Fats \& oils (46) } & Rebate $=0$ & & & & & & & & 27 & 27 & 27 & 27 \\
\hline & Export tax & & & & & & & & & & & \\
\hline & Both & & & & & & & & & & & \\
\hline \multirow{3}{*}{ Beverages \& tobacco (183) } & Rebate $=0$ & & & 3 & 3 & 4 & 6 & 6 & 4 & 4 & 6 & 6 \\
\hline & Export tax & & & & & & & & & & & \\
\hline & Both & & & & & & & & & & & \\
\hline \multirow{3}{*}{ Minerals (148) } & Rebate $=0$ & & & 48 & 48 & 54 & 122 & 138 & 137 & 137 & 137 & 137 \\
\hline & Export tax & 3 & 3 & 1 & 1 & 5 & 44 & 47 & 62 & 59 & 59 & 59 \\
\hline & Both & & & 1 & 1 & 5 & 44 & 47 & 61 & 58 & 58 & 58 \\
\hline \multirow{3}{*}{ Chemicals (779) } & Rebate $=0$ & & & 4 & 11 & 18 & 20 & 219 & 207 & 207 & 263 & 265 \\
\hline & Export tax & 1 & 1 & 1 & 2 & 3 & 9 & 19 & 44 & 41 & 41 & 42 \\
\hline & Both & & & & 2 & 1 & 4 & 18 & 41 & 38 & 38 & 39 \\
\hline \multirow{3}{*}{ Plastics (209) } & Rebate $=0$ & & & & & & & & & & 19 & 19 \\
\hline & Export tax & & & & & & & & & & & \\
\hline & Both & & & & & & & & & & & \\
\hline \multirow{3}{*}{ Leather (73) } & Rebate $=0$ & & & & & 29 & 36 & 42 & 42 & 42 & 42 & 42 \\
\hline & Export tax & & & & & 1 & 1 & & 1 & 1 & 1 & 1 \\
\hline & Both & & & & & 1 & 1 & & 1 & 1 & 1 & 1 \\
\hline \multirow{3}{*}{ Wood products (65) } & Rebate $=0$ & & & 24 & 24 & 28 & 34 & 34 & 34 & 34 & 34 & 36 \\
\hline & Export tax & & & & & & 5 & 5 & 5 & 5 & 5 & 5 \\
\hline & Both & & & & & & 3 & 3 & 3 & 3 & 3 & 3 \\
\hline \multirow{3}{*}{ Paper (148) } & Rebate $=0$ & & & 96 & 96 & 96 & 90 & 90 & 88 & 88 & 88 & 87 \\
\hline & Export tax & & & & & & & 14 & 14 & 14 & 14 & 14 \\
\hline & Both & & & & & & & 14 & 14 & 14 & 14 & 14 \\
\hline \multirow{3}{*}{ Stone \& glass (125) } & Rebate $=0$ & & & & & & 17 & 17 & 17 & 17 & 29 & 28 \\
\hline & Export tax & & & & & & & & & & & \\
\hline & Both & & & & & & & & & & & \\
\hline \multirow{3}{*}{ Pearls (48) } & Rebate $=0$ & & & 8 & 8 & 12 & 15 & 15 & 17 & 17 & 18 & 18 \\
\hline & Export tax & & & & & & & & & & & \\
\hline & Both & & & & & & & & & & & \\
\hline \multirow{3}{*}{ Metals (575) } & Rebate $=0$ & & & 15 & 34 & 50 & 101 & 175 & 126 & 126 & 200 & 200 \\
\hline & Export tax & 3 & 3 & 6 & 20 & 33 & 60 & 135 & 101 & 94 & 94 & 94 \\
\hline & Both & & & & 12 & 23 & 56 & 128 & 95 & 88 & 91 & 91 \\
\hline
\end{tabular}

Source: Authors' computations. 
Table 4: Determinants of the export VAT rebate

\begin{tabular}{|c|c|c|c|c|c|c|}
\hline Dependent variable & \multicolumn{6}{|c|}{ Export VAT cost } \\
\hline & (1) & (2) & (3) & (4) & (5) & (6) \\
\hline Sophistication & $\begin{array}{c}-1.588^{\star * *} \\
(.348)\end{array}$ & $\begin{array}{c}-0.962^{\star * *} \\
(.297)\end{array}$ & & $\begin{array}{c}-1.033^{*} \\
(.325)\end{array}$ & $\begin{array}{c}-0.934^{\star * *} \\
(.298)\end{array}$ & $\begin{array}{c}-0.962^{* \star *} \\
(.297)\end{array}$ \\
\hline $\begin{array}{l}\text { Technology } \\
\text { intensity }\end{array}$ & & & $-3.783 * \star *$ & & & \\
\hline Medium & & & $\begin{array}{c}(.752) \\
-4.262 * \star *\end{array}$ & & & \\
\hline High & & & $(.747)$ & & & \\
\hline $\begin{array}{l}\mathrm{SO}_{2} \text { emitting } \\
\text { products }\end{array}$ & $\begin{array}{l}0.964^{\star \star \star} \\
(.210)\end{array}$ & $\begin{array}{c}1.012^{\star \star \star} \\
(.213)\end{array}$ & $\begin{array}{c}0.837^{\star \star \star} \\
(.209)\end{array}$ & & $\begin{array}{c}1.008^{\star \star \star} \\
(.213)\end{array}$ & $\begin{array}{c}1.012^{\star \star \star} \\
(.212)\end{array}$ \\
\hline $\begin{array}{l}\text { Water polluting } \\
\text { products }\end{array}$ & $\begin{array}{c}1.49 \\
(.983)\end{array}$ & $\begin{array}{l}1.581^{*} \\
(.936)\end{array}$ & $\begin{array}{c}2.289^{* *} \\
(.905)\end{array}$ & $\begin{array}{c}1.831^{\star * *} \\
(.597)\end{array}$ & $\begin{array}{l}1.595^{\star} \\
(.936)\end{array}$ & $\begin{array}{l}1.581^{*} \\
(.936)\end{array}$ \\
\hline $\begin{array}{l}\text { Energy-intensive } \\
\text { products }\end{array}$ & & & & $\begin{array}{c}3.541^{\star \star \star} \\
(.770)\end{array}$ & & \\
\hline $\begin{array}{l}\text { Growth of the world } \\
\text { market share (lag) }\end{array}$ & $\begin{array}{c}0.297 * \star \star \\
(.072)\end{array}$ & $\begin{array}{c}0.242^{\star \star \star} \\
(.068)\end{array}$ & $\begin{array}{l}0.215^{\star \star *} \\
(.057)\end{array}$ & $\begin{array}{l}0.223^{\star \star \star} \\
(.059)\end{array}$ & $\begin{array}{c}0.244^{\star * *} \\
(.068)\end{array}$ & $\begin{array}{l}0.242^{\star \star \star} \\
(.068)\end{array}$ \\
\hline $\begin{array}{l}\text { Food and beverages } \\
\text { (F\&B) for } \\
\text { households }\end{array}$ & $\begin{array}{l}0.820 \\
(.617)\end{array}$ & $\begin{array}{c}1.367^{\star \star} \\
(.556)\end{array}$ & $\begin{array}{l}0.933 \\
(.601)\end{array}$ & $\begin{array}{l}0.475 \\
(.591)\end{array}$ & & $\begin{array}{c}1.367^{\star \star} \\
(.556)\end{array}$ \\
\hline $\begin{array}{l}\text { Primary F\&B for } \\
\text { households }\end{array}$ & & & & & $\begin{array}{c}1.667^{\star \star} \\
(.656)\end{array}$ & \\
\hline $\begin{array}{c}\text { Processed F\&B for } \\
\text { households }\end{array}$ & & & & & $\begin{array}{l}1.172^{*} \\
(.609)\end{array}$ & \\
\hline $\begin{array}{l}\text { Primary products } \\
\text { for industry }\end{array}$ & & $\begin{array}{c}5.208^{\star \star \star} \\
(.636)\end{array}$ & $\begin{array}{c}4.375^{\star \star \star} \\
(.474)\end{array}$ & $\begin{array}{c}5.370^{* \star *} \\
(.693)\end{array}$ & & $\begin{array}{c}5.208^{\star \star \star} \\
(.636)\end{array}$ \\
\hline $\begin{array}{l}\text { Primary F\&B for } \\
\text { industry }\end{array}$ & & & & & $\begin{array}{c}3.061^{\star \star \star} \\
(.690)\end{array}$ & \\
\hline $\begin{array}{l}\text { Primary industrial } \\
\text { products for } \\
\text { industry }\end{array}$ & & & & & $\begin{array}{c}5.472^{\star \star \star} \\
(.613)\end{array}$ & \\
\hline Rare earths & & $\begin{array}{c}5.317^{\star \star \star} \\
(.879)\end{array}$ & $\begin{array}{c}4.672^{\star \star \star} \\
(.805)\end{array}$ & $\begin{array}{c}4.930^{\star \star \star} \\
(.644)\end{array}$ & $\begin{array}{c}5.219^{\star \star \star} \\
(.890)\end{array}$ & $\begin{array}{l}5.317^{\star} \\
(.879)\end{array}$ \\
\hline $\begin{array}{c}\text { Revealed } \\
\text { comparative } \\
\text { advantage (lag) }\end{array}$ & & $\begin{array}{l}-0.644^{\star \star} \\
(.304)\end{array}$ & $\begin{array}{c}-0.732^{\star \star \star} \\
(.251)\end{array}$ & $\begin{array}{c}-0.647^{\star *} \\
(.278)\end{array}$ & $\begin{array}{c}-0.651^{* \star} \\
(.303)\end{array}$ & $\begin{array}{c}-0.644^{* *} \\
(.304)\end{array}$ \\
\hline Fixed effects & & & Sector-ye & $r($ GBT1) & & \\
\hline Observations & 37984 & 37984 & 37984 & 37984 & 37984 & 37984 \\
\hline R-squared (within) & 0.29 & 0.36 & 0.45 & 0.40 & 0.36 & 0.36 \\
\hline
\end{tabular}

Note: Heteroskedasticity-robust standard errors are reported in parentheses. Standard errors are clustered at the 2-digit sector level. **, ** and * indicate significance at the $1 \%, 5 \%$ and $10 \%$ confidence level. 
Table 5: Determinants of the export tax

\begin{tabular}{|c|c|c|c|c|c|c|}
\hline Dependent variable & \multicolumn{6}{|c|}{ Export tax } \\
\hline & $(1)$ & (2) & (3) & (4) & (5) & (6) \\
\hline Sophistication & $\begin{array}{l}-0.901^{\star \star \star} \\
(.327)\end{array}$ & $\begin{array}{l}-0.610^{\star \star \star} \\
(.196)\end{array}$ & & $\begin{array}{l}-0.607^{\star \star \star} \\
(.194)\end{array}$ & $\begin{array}{l}-0.605^{\star \star \star} \\
(.195)\end{array}$ & $\begin{array}{l}-0.533^{\star \star \star} \\
(.171)\end{array}$ \\
\hline $\begin{array}{c}\text { Technology intensity } \\
\text { Medium } \\
\text { High }\end{array}$ & & & $\begin{array}{l}-0.822^{\star \star \star} \\
(.247) \\
-1.118^{\star \star \star} \\
(.408)\end{array}$ & & & \\
\hline $\mathrm{SO}_{2}$ emitting products & $\begin{array}{l}-0.307 \\
(.305)\end{array}$ & $\begin{array}{l}-0.290 \\
(.291)\end{array}$ & $\begin{array}{l}-0.334 \\
(.271)\end{array}$ & & $\begin{array}{l}-0.293 \\
(.290) \\
\end{array}$ & \\
\hline $\begin{array}{l}\text { Water polluting } \\
\text { products }\end{array}$ & $\begin{array}{l}4.510 * \star \star \\
(.770)\end{array}$ & $\begin{array}{l}4.548^{\star \star \star} \\
(.810)\end{array}$ & $\begin{array}{l}4.734^{\star \star \star} \\
(.865)\end{array}$ & $\begin{array}{l}4.202^{\star \star \star} \\
(.590)\end{array}$ & $\begin{array}{l}4.559 * \star \star \\
(.810)\end{array}$ & $\begin{array}{l}3.618^{\star \star *} \\
(.465)\end{array}$ \\
\hline $\begin{array}{l}\text { Energy-intensive } \\
\text { products }\end{array}$ & & & & $\begin{array}{l}-0.292 \\
(.376)\end{array}$ & & \\
\hline $\begin{array}{l}\text { Growth of the world } \\
\text { market share (lag) }\end{array}$ & $\begin{array}{l}0.138^{*} \\
(.075)\end{array}$ & $\begin{array}{l}0.109 \\
(.078)\end{array}$ & $\begin{array}{l}0.114 \\
(.079)\end{array}$ & $\begin{array}{l}0.118 \\
(.081)\end{array}$ & $\begin{array}{l}0.111 \\
(.078)\end{array}$ & \\
\hline $\begin{array}{l}\text { Food and beverages } \\
\text { (F\&B) for households }\end{array}$ & $\begin{array}{l}-0.066 \\
(.298)\end{array}$ & $\begin{array}{l}0.167 \\
(.285)\end{array}$ & $\begin{array}{l}0.045 \\
(.264)\end{array}$ & $\begin{array}{l}0.272 \\
(.285)\end{array}$ & & \\
\hline $\begin{array}{l}\text { Primary F\&B for } \\
\text { households }\end{array}$ & & & & & $\begin{array}{l}-0.186 \\
(.430)\end{array}$ & \\
\hline $\begin{array}{l}\text { Processed F\&B for } \\
\text { households }\end{array}$ & & & & & $\begin{array}{l}0.072 \\
(.232)\end{array}$ & \\
\hline $\begin{array}{c}\text { Primary products for } \\
\text { industry }\end{array}$ & & $\begin{array}{l}2.240^{\star \star} \\
(.931)\end{array}$ & $\begin{array}{l}2.285^{\star \star} \\
(.923)\end{array}$ & $\begin{array}{l}2.292^{\star \star} \\
(.913)\end{array}$ & & $\begin{array}{l}1.979 \star \star \\
(.750)\end{array}$ \\
\hline $\begin{array}{c}\text { Primary F\&B for } \\
\text { industry }\end{array}$ & & & & & $\begin{array}{l}-0.337 \\
(.293)\end{array}$ & \\
\hline $\begin{array}{l}\text { Primary industrial } \\
\text { products for industry }\end{array}$ & & & & & $\begin{array}{l}2.511^{\star \star *} \\
(.928)\end{array}$ & \\
\hline Rare earths & & $\begin{array}{l}5.129 * \star \star \\
(1.450)\end{array}$ & $\begin{array}{l}5.016^{\star \star \star} \\
(1.520)\end{array}$ & $\begin{array}{l}5.094^{\star \star *} \\
(1.503)\end{array}$ & $\begin{array}{l}5.019 * \star \star \\
(1.460)\end{array}$ & $\begin{array}{l}4.709^{\star \star \star} \\
(1.311)\end{array}$ \\
\hline $\begin{array}{l}\text { Revealed comparative } \\
\text { advantage (lag) }\end{array}$ & & $\begin{array}{l}-0.276^{\star \star} \\
(.149)\end{array}$ & $\begin{array}{l}-0.261^{*} \\
(.135)\end{array}$ & $\begin{array}{l}-0.254^{*} \\
(.147)\end{array}$ & $\begin{array}{l}-0.281^{*} \\
(.149)\end{array}$ & $\begin{array}{l}-0.231^{*} \\
(.129)\end{array}$ \\
\hline Fixed effects & & & Sector-y & $\operatorname{ar}(\mathrm{GBT} 1)$ & & \\
\hline Observations & 37984 & 37984 & 37984 & 37984 & 37984 & 37984 \\
\hline R-squared (within) & 0.16 & 0.18 & 0.18 & 0.18 & 0.18 & 0.16 \\
\hline
\end{tabular}

Note: Heteroskedasticity-robust standard errors are in parentheses. Standard errors are clustered at the 2digit sector level. ***, ** and * indicate significance at the 1\%, 5\% and 10\% confidence level. 
Table 6: Determinants of the export VAT cost: yearly regressions

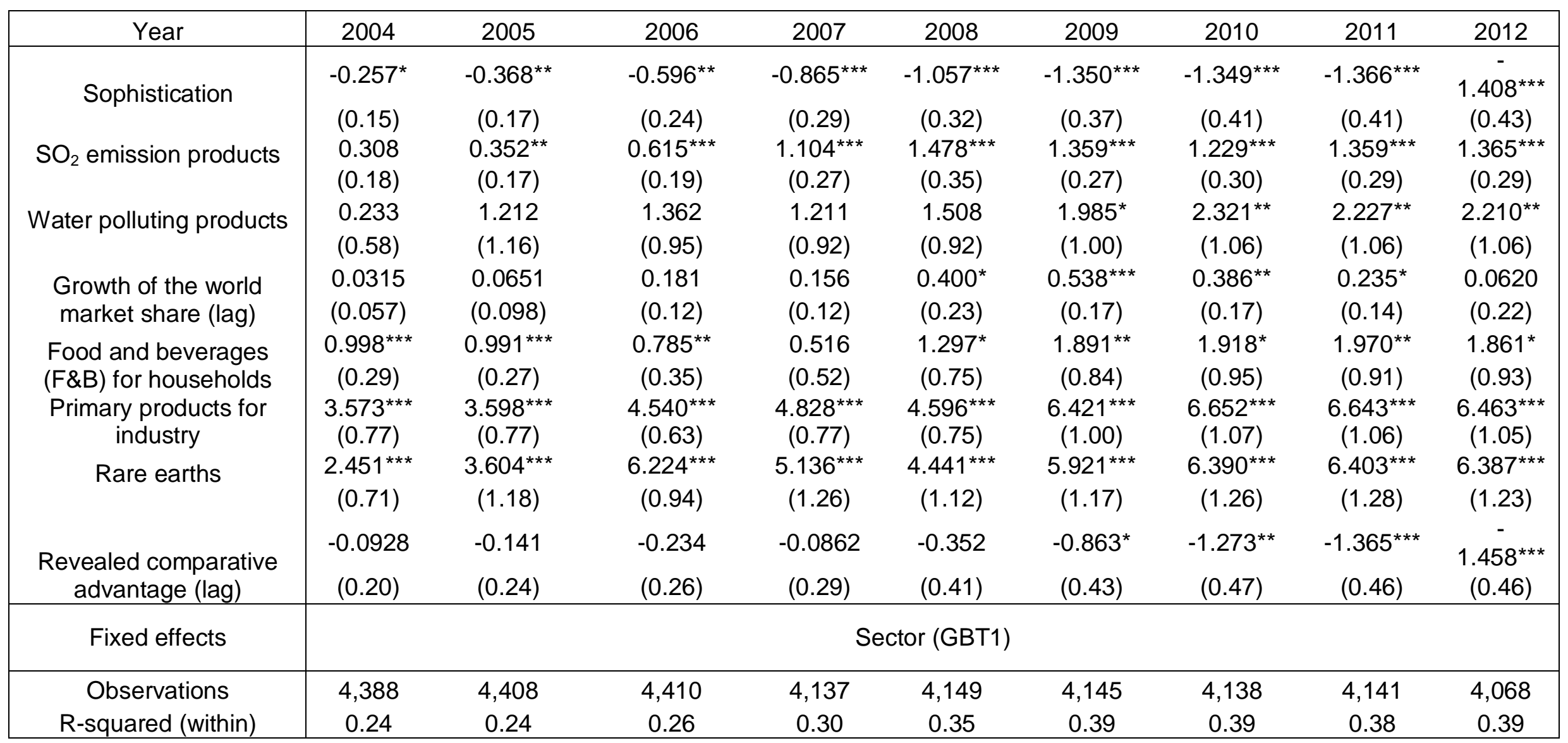

Heteroskedasticity-robust standard errors are reported in parentheses. Standard errors are clustered at the 2-digit sector level. ***, ** and * indicate significance at the $1 \%, 5 \%$ and $10 \%$ confidence level. 
Table 7: Determinants of the export Tax: yearly regressions

\begin{tabular}{|c|c|c|c|c|c|c|c|c|c|}
\hline Year & 2004 & 2005 & 2006 & 2007 & 2008 & 2009 & 2010 & 2011 & 2012 \\
\hline Sophistication & $\begin{array}{l}-0.039 \\
(0.04)\end{array}$ & $\begin{array}{l}-0.058 \\
(0.04)\end{array}$ & $\begin{array}{l}-0.280 \\
(0.02)\end{array}$ & $\begin{array}{l}-0.355^{\star} \\
(0.019)\end{array}$ & $\begin{array}{c}-0.459 * * \\
(0.02)\end{array}$ & $\begin{array}{l}-1.314^{\star \star \star} \\
(0.05)\end{array}$ & $\begin{array}{c}-0.799 * \star \star \\
(0.02)\end{array}$ & $\begin{array}{c}-0.815^{\star \star \star} \\
(0.02)\end{array}$ & $\begin{array}{c}- \\
0.947^{\star \star *} \\
(0.03)\end{array}$ \\
\hline Water-pollution products & & & & & & $11.95^{\star \star \star}$ & & $6.694^{\star \star \star}$ & \\
\hline $\begin{array}{l}\text { Primary products for } \\
\text { industry }\end{array}$ & $\begin{array}{l}(0.10) \\
0.036 \\
(0.03)\end{array}$ & $\begin{array}{l}(0.07) \\
0.089 \\
(0.08)\end{array}$ & $\begin{array}{l}(0.12) \\
1.669 * \\
(0.09)\end{array}$ & $\begin{array}{c}(0.67) \\
3.248^{\star \star} \\
(1.47)\end{array}$ & $\begin{array}{c}(1.18) \\
1.892^{\star \star} \\
(0.73)\end{array}$ & $\begin{array}{c}(3.19) \\
4.695^{\star \star \star} \\
(1.06)\end{array}$ & $\begin{array}{c}(0.77) \\
4.058^{\star \star \star} \\
(1.24)\end{array}$ & $\begin{array}{c}(0.85) \\
4.069^{* \star *} \\
(1.24)\end{array}$ & $\begin{array}{c}(1.38) \\
4.084^{\star \star \star} \\
(1.22)\end{array}$ \\
\hline Rare earths & $\begin{array}{l}0.409 \\
(0.45)\end{array}$ & $\begin{array}{l}0.351 \\
(0.46)\end{array}$ & $\begin{array}{l}-0.351 \\
(1.35)\end{array}$ & $\begin{array}{l}2.761^{*} \\
(1.50)\end{array}$ & $\begin{array}{c}8.392^{\star \star \star} \\
(1.58)\end{array}$ & $\begin{array}{c}10.46^{\star \star \star} \\
(3.02)\end{array}$ & $\begin{array}{l}7.468^{\star \star \star} \\
(2.46)\end{array}$ & $\begin{array}{c}7.438^{\star \star \star} \\
(2.46)\end{array}$ & $\begin{array}{l}7.152^{\star \star \star} \\
(2.48)\end{array}$ \\
\hline $\begin{array}{c}\text { Revealed comparative } \\
\text { advantage (lag) }\end{array}$ & $\begin{array}{l}0.015 \\
(0.01) \\
\end{array}$ & $\begin{array}{l}0.001 \\
(0.02) \\
\end{array}$ & $\begin{array}{c}-0.093 \\
(0.08) \\
\end{array}$ & $\begin{array}{l}-0.102 \\
(0.11) \\
\end{array}$ & $\begin{array}{l}0.006 \\
(0.15) \\
\end{array}$ & $\begin{array}{l}-0.464 \\
(0.41)\end{array}$ & $\begin{array}{l}-0.401^{*} \\
(0.23)\end{array}$ & $\begin{array}{l}-0.374 \\
(0.23)\end{array}$ & $\begin{array}{l}-0.271 \\
(0.20)\end{array}$ \\
\hline Fixed effects & \multicolumn{9}{|c|}{ Sector (GBT1) } \\
\hline $\begin{array}{c}\text { Observations } \\
\text { R-squared (within) }\end{array}$ & $\begin{array}{c}4,616 \\
0.02\end{array}$ & $\begin{array}{c}4,618 \\
0.02\end{array}$ & $\begin{array}{c}4,627 \\
0.06\end{array}$ & $\begin{array}{l}4,331 \\
0.15\end{array}$ & $\begin{array}{c}4,331 \\
0.19\end{array}$ & $\begin{array}{c}4,330 \\
0.38\end{array}$ & $\begin{array}{c}4,330 \\
0.28\end{array}$ & $\begin{array}{c}4,330 \\
0.28\end{array}$ & $\begin{array}{c}4,256 \\
0.34\end{array}$ \\
\hline
\end{tabular}

Heteroskedasticity-robust standard errors are in parentheses. Standard errors are clustered at the 2-digit sector level. ***, ** and * indicate significance at the $1 \%, 5 \%$ and $10 \%$ confidence level. 
Figure 3: Explanatory power of export VAT cost determinants over 2004-2012

Sophistication

Growth of world MS

Rare earths
SO2 emission

F\&B for households

RCA
Water pollution

Primary products for industry

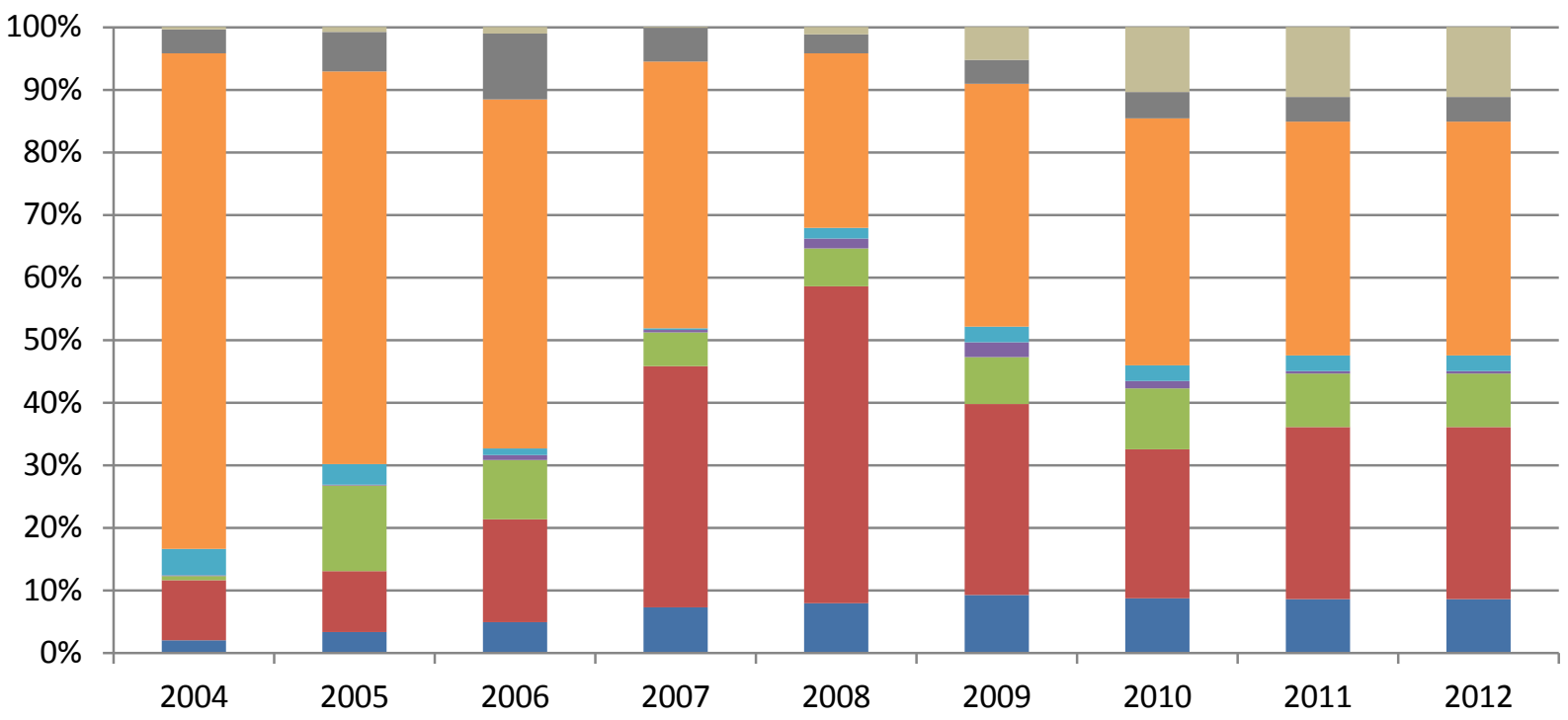

Note: Figures come from the coefficients in Table 8

Figure 4: Explanatory power of export tax determinants over 2007-2012

- Sophistication $\square$ Water pollution $\square$ Primary products for industry $\square$ Rare earths $\square$ RCA

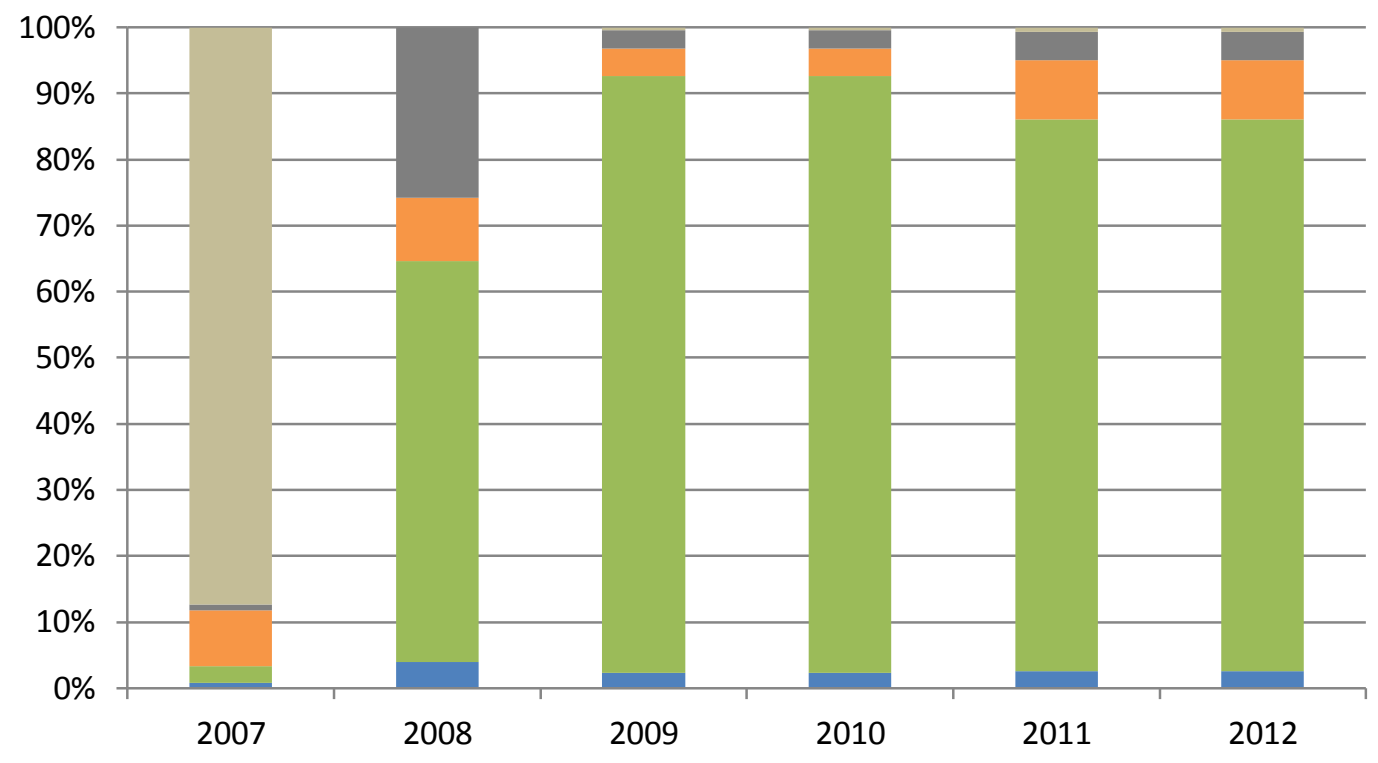

Note: Figures come from the coefficients in Table 9 
Table 8: ANOVA on export VAT cost

\begin{tabular}{|c|c|c|c|c|c|c|c|c|}
\hline $\begin{array}{l}\text { Share of } \\
\text { variance } \\
\text { explaine } \\
\text { d by: }\end{array}$ & $\begin{array}{l}\text { Sophi- } \\
\text { stication }\end{array}$ & $\begin{array}{c}\mathrm{SO}_{2} \\
\text { emissions }\end{array}$ & $\begin{array}{c}\text { Water } \\
\text { pollution }\end{array}$ & $\begin{array}{l}\text { Growth } \\
\text { of world } \\
\text { market } \\
\text { share }\end{array}$ & $\begin{array}{c}\text { F\&B for } \\
\text { households }\end{array}$ & $\begin{array}{l}\text { Primary } \\
\text { products for } \\
\text { industry }\end{array}$ & $\begin{array}{l}\text { Rare } \\
\text { earths }\end{array}$ & $\begin{array}{c}\text { Comparative } \\
\text { advantage (RCA) }\end{array}$ \\
\hline 2004 & 2.10 & 9.58 & 0.64 & 0.05 & 4.28 & 79.08 & 3.81 & 0.45 \\
\hline 2005 & 4.96 & 16.39 & 9.47 & 0.77 & 1.14 & 55.67 & 10.51 & 1.09 \\
\hline 2006 & 7.30 & 38.51 & 5.39 & 0.36 & 0.36 & 42.53 & 5.44 & 0.10 \\
\hline 2007 & 8.04 & 50.58 & 6.08 & 1.51 & 1.68 & 27.95 & 2.97 & 1.19 \\
\hline 2008 & 9.31 & 30.52 & 7.49 & 2.33 & 2.57 & 38.73 & 3.75 & 5.32 \\
\hline 2009 & 8.80 & 23.71 & 9.82 & 1.09 & 2.51 & 39.51 & 4.20 & 10.36 \\
\hline 2010 & 8.60 & 27.51 & 8.53 & 0.39 & 2.49 & 37.39 & 3.97 & 11.12 \\
\hline 2011 & 8.60 & 27.51 & 8.53 & 0.39 & 2.49 & 37.39 & 3.97 & 11.12 \\
\hline 2012 & 2.10 & 9.58 & 0.64 & 0.05 & 4.28 & 79.08 & 3.81 & 0.45 \\
\hline $\begin{array}{c}2004- \\
2012\end{array}$ & 7.87 & 27.94 & 7.93 & 0.79 & 2.18 & 43.34 & 4.95 & 4.99 \\
\hline
\end{tabular}

Note: Analysis of variance is based on a model with sector-year fixed effects. 
Table 9: ANOVA on export tax

\begin{tabular}{|c|c|c|c|c|c|}
\hline $\begin{array}{c}\text { Share of } \\
\text { variance } \\
\text { explained } \\
\text { by: }\end{array}$ & Sophistication & $\begin{array}{c}\text { Water } \\
\text { pollution }\end{array}$ & $\begin{array}{l}\text { Primary } \\
\text { products } \\
\text { for } \\
\text { industry }\end{array}$ & $\begin{array}{l}\text { Rare } \\
\text { earths }\end{array}$ & $\begin{array}{c}\text { Comparative } \\
\text { advantage } \\
\text { (RCA) }\end{array}$ \\
\hline 2007 & 5.84 & 20.71 & 65.73 & 7.05 & 684.62 \\
\hline 2008 & 3.99 & 60.60 & 9.60 & 25.81 & 0.00 \\
\hline 2009 & 2.26 & 90.42 & 4.08 & 2.84 & 0.40 \\
\hline 2010 & 2.26 & 90.42 & 4.08 & 2.84 & 0.40 \\
\hline 2011 & 2.63 & 83.41 & 8.97 & 4.28 & 0.72 \\
\hline 2012 & 2.63 & 83.41 & 8.97 & 4.28 & 0.72 \\
\hline $\begin{array}{l}2007- \\
2012 \\
\end{array}$ & 2.88 & 83.00 & 8.67 & 4.89 & 0.56 \\
\hline
\end{tabular}

Note: Analysis of variance is based on a model with sector-year fixed effects. 